\title{
Forecasting of a Thermal Condition of Pneumatic Tires of Dump Trucks
}

\author{
Anna Kvasova ${ }^{1, *}$, Boris Gerike ${ }^{1}$, Elena Murko $^{1}$ and Dmitriy Skudarnov ${ }^{1,2}$ \\ ${ }^{1}$ T.F. Gorbachev Kuzbass State Technical University, 650000 Kemerovo, Russia \\ 2 VIST GRUPP, 650002 Kemerovo, Russia
}

\begin{abstract}
Over the last 10 years the world consumption of coal has grown almost by $50 \%$. Coal is one of the main energy resources capable to satisfy basic energy demands of increasing population and developing world economy. On January 24, 2012 the long-term Coal Industry Development Program for the period till 2030 was approved in Russia. According to this Program coal mining in Kuzbass in 2030 will make 260 million tonns of coal per year. Development of the coal industry is impossible without upgrade of coal production by avoiding inefficient technological, organizational and economic solutions. Off the road (OTR) tires play an important role in ensuring effective, continuous and safe work of mining motor transport.
\end{abstract}

\section{Introduction}

At present time open pit mining is the growing segment of coal industry of Kuzbass - region with 210 million tons of coal mined annually [1-2]. So ecological and economic problems here is increase simultaneously with growth of open pot coal mining [3-5].

In cost value of one tonne of the transported products using an open-cut method of exploitation of mineral deposits $65 \%$ are occupied by costs for motor transport $18 \%$ of which are costs for tires. Not by coincidence purchase and service of OTR tires are among main expenditure items of the open coal mining enterprises. Considering a major role of OTR tires both in the expenditure pattern, and in the technical support of mining operations, the leading manufacturers and consumers of OTR tires are interested in maximum effective management of tire supply.

JSC "Razrez Berezovskiy" of the group of LLC "Stroyservis" enterprises use heavy payload dumper trucks: BelAZ-75306 (loading capacity of 220 t) and Komatsu HD830E (loading capacity of $231 \mathrm{t}$ ). These dump trucks are equipped with tires of standard sizes: 40.00-57 and 46/90-57.

According to JSC "Razrez Berezovskiy", in 2017 in operation there are 258 tires of standard sizes 40.00-57 and 46/90-57, what is 72 pieces more in comparison with 2016. It is connected with commissioning in 2017 of four new dump trucks: BelAZ-75306 and nine dump trucks Komatsu HD830E. From the analysis of tire accidental failures, it is revealed that the number of tires written-off because of the natural wear in January-April, 2017 is 11

\footnotetext{
*Corresponding author: kvasovaaa@kuzstu.ru
} 
pieces more than for the similar period in 2016, and because of the accidental failure it is 70 pieces more.

Table 1. Number of tires for BelAZ-75306 dump trucks (35 dump trucks in operation).

\begin{tabular}{|c|c|c|}
\hline Tire model & $\begin{array}{c}\text { Number of tires } \\
\text { in use, pcs. }\end{array}$ & $\begin{array}{c}\text { Standard operational } \\
\text { kilometers }\end{array}$ \\
\hline 40.00 R57 Michelin XDR & 27 & 105000 \\
\hline 40.00 R57 Bridgestone VELS E-4 & 24 & 110000 \\
\hline 40.00 R57 LUAN HA-368 & 1 & 65000 \\
\hline 40.00 R57 Yokohama & 15 & 60000 \\
\hline 40.00-57 Goodyear & 10 & 100000 \\
\hline 46/90-57 Goodyear RM-4B+**4SL & 60 & 100000 \\
\hline 46.90 R57 LUAN HA-569 & 5 & 65000 \\
\hline 46/90 R57 Bridgestone VRPS E-4 & 4 & 110000 \\
\hline $46 / 90-57$ Belshina Bel-160D & 43 & 47000 \\
\hline 40.00 R57 LUAN HA-368 & 1 & 65000 \\
\hline
\end{tabular}

Table 2. Number of tires for Komatsu HD830E dump trucks (19 dump trucks in operation)

\begin{tabular}{|c|c|c|}
\hline Tire model & $\begin{array}{c}\text { Number of tires } \\
\text { in use, pes. }\end{array}$ & $\begin{array}{c}\text { Standard operational } \\
\text { kilometers }\end{array}$ \\
\hline 40.00 R57 Michelin XDR & 71 & 105000 \\
\hline 40.00 R57 Bridgestone VELS E-4 & 12 & 110000 \\
\hline 40.00-57 Goodyear & 6 & 100000 \\
\hline 46/90-57 Goodyear RM-4B+**4SL & 24 & 100000 \\
\hline 46/90-57 Belshina Bel-160D & 1 & 47000 \\
\hline
\end{tabular}

Table 3. Data on tires life and write-off in 2016 and 2017 (January-April)

\begin{tabular}{|c|c|c|c|c|c|c|}
\hline \multirow{2}{*}{ Tire brand } & \multirow{2}{*}{$\begin{array}{c}\text { Average } \\
\text { actual life } \\
\text { in } 2016, \\
\% \\
\end{array}$} & \multicolumn{2}{|c|}{$\begin{array}{c}\text { Number of tires } \\
\text { written-off in 2016, pes. }\end{array}$} & \multirow{2}{*}{$\begin{array}{c}\text { Average } \\
\text { actual life } \\
\text { in } 2017, \\
\%\end{array}$} & \multicolumn{2}{|c|}{$\begin{array}{c}\text { Number of tires } \\
\text { written-off in 2017, pes. }\end{array}$} \\
\hline & & $\begin{array}{c}\text { Natural } \\
\text { wear }\end{array}$ & $\begin{array}{c}\text { Accidental } \\
\text { failure }\end{array}$ & & $\begin{array}{c}\text { Natural } \\
\text { wear }\end{array}$ & $\begin{array}{c}\text { Accidental } \\
\text { failure }\end{array}$ \\
\hline Luan & - & - & - & 49.9 & - & 4 \\
\hline Bridgestone & 80.3 & 6 & 5 & 66.35 & 5 & 16 \\
\hline Michelin & 68.8 & 0 & 5 & 63.5 & 4 & 27 \\
\hline Yokohama & 83.8 & 2 & 0 & 50.1 & 3 & 18 \\
\hline Goodyear & 82.2 & 3 & 5 & 68.8 & 12 & 9 \\
\hline
\end{tabular}




\begin{tabular}{|c|c|c|c|c|c|c|}
\hline Belshina & 101.1 & 11 & 1 & 66.1 & 9 & 12 \\
\hline TOTAL & 85.94 & 22 & 16 & 62.56 & 33 & 86 \\
\hline
\end{tabular}

\section{Experimental research}

Losses of the enterprise in 2016 due to reduction of operational kilometers made 116.8 million rubles.

As the main materials and adhesives used for production of tires are sensitive to high temperatures, OTR tire life substantially depends on its thermal condition. Quite often the generation of temperatures in OTR tires used on dump trucks reaches the maximum, that is caused by their low cooling rate. The reason of it is the feature of tire design that has big thickness. Especially it is easy to see in summer, when the average level of OTP tire life considerably decreases because of the tires which failed as a result of thermal destructions (up to $70 \%$ of all failures). When the internal temperature of a tire reaches extreme values $\left(110^{\circ} \mathrm{C}\right)$, the emergence of the phenomenon of rubber pyrolysis is probable, that leads to release of combustion gases (methane, hydrogen), sharp increase in internal pressure in the tire which in the presence of oxygen can lead to ignition and blow-out of the tire.

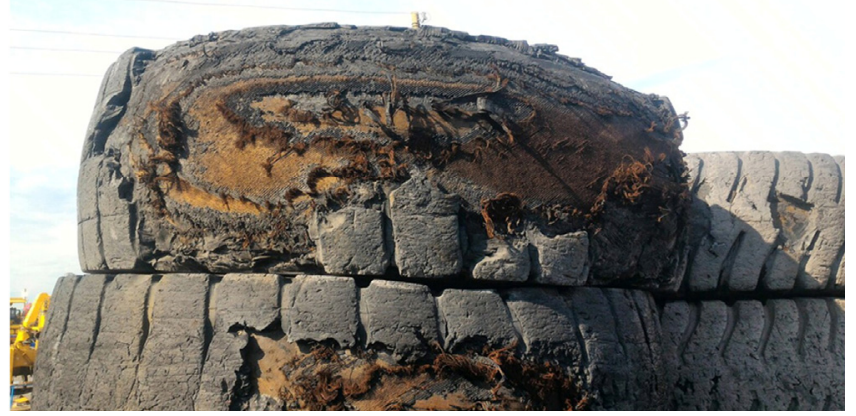

Fig. 1. The tires failed as a result of thermal destructions

It is possible to reduce failures of tires because of thermal destructions. In order to prevent increase of heat generation, it is necessary, following the operation manual of OTR tires, prevent exceeding of the working capacity indicator "tonnes-kilometers per hour" (TKPH), as the internal temperature of the tire directly depends on this indicator (fig. 2).

During the work of dump trucks there is alternately a warming up and a cooling of tires because of stops for loading and unloading, lunch breaks and shift turnarounds.

Working capacity TKPH can be calculated by the formula:

$$
T K P H=Q a v \cdot * V a v \cdot w .
$$

where: Qav - average load of a tire, t; Vav.w. - average working speed of a dump truck, $\mathrm{km} / \mathrm{h}$.. 


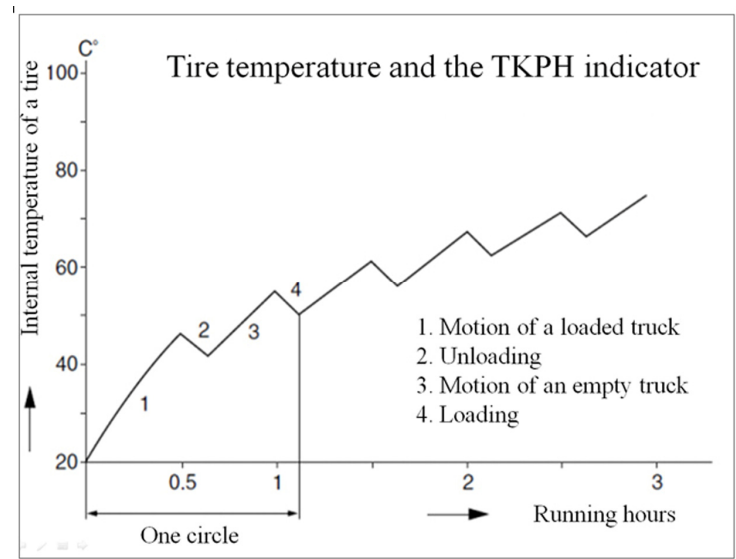

Fig. 2. Dependence of internal temperature of the tire on the TKPH indicator

\section{Conclusions}

The JSC "Razrez Berezovskiy" enterprise refused use of OTR tires 46/90-57 Belshina Bel160D and 40.00 R57 Yokohama on Komatsu HD830E dump trucks because of frequent accidental failures, but, due to the lack of tires of other brands in the material warehouse, they are anyway installed periodically on these dump trucks by production necessity. TKPH values for these tires are 680 and 598 respectively. The average distance of transportation by Komatsu HD830E dump trucks is $4.5 \mathrm{~km}$, average working speed is $14.5 \mathrm{~km} / \mathrm{h}$. As per calculations, in order to prevent exceeding of the admissible TKPH indicator, these dump trucks should make no more than 14-16 runs per shift, in fact they perform 22-25 runs per shift that corresponds to the working capacity indicator of 913-1038 TKPH. Working speed of dump trucks BelAZ-75306 is $12.6 \mathrm{~km} / \mathrm{h}$, therefore they perform less runs per shift and the tires 46/90-57 Belshina Bel-160D and 40.00 R57 Yokohama on these dump trucks work better.

Also, low pressure in a tire, partial transfer of heat from brakes and gears, slipping, overload, exceeding of a speed limit can be the cause of thermal destructions of OTR tires, however, a lot of attention is paid to control these factors. As for working capacity, now the enterprises perform calculations of the TKPH indicator only after failures of OTR tires for identification of failure causes, however, forecasting and control of the TKPH indicator of working capacity in modern conditions is an important task of the mining enterprises. If the predicted TKPH indicator is higher than the standard one, it can be corrected by changing of the load of a tire, dump truck speed, transportation distance, and idle times.

\section{References}

1. M.A. Tyulenev, T.N. Gvozdkova, S.A. Zhironkin, E.A. Garina, Geotech. Geol. Eng., 35:1, 203-212 (2017)

2. M. Tyulenev, S. Zhironkin, E. Tyuleneva, A. Abay, S. Anyona, M. Hellmer, Coal Int., 265:3, 30-34 (2017)

3. S.A. Prokopenko, V.S. Gornyi Zhurnal, 1, 47-49 (2014)

4. T.V. Galanina, M.I. Baumgarten, V.G. Mikhailov, T.G. Koroleva, G.S. Mikhailov, IOP Conf. Ser.: Earth Environ. Sci., 50:1, 012030 (2017)

5. T.V. Kiseleva, V.G. Mikhailov, V.A. Karasev, IOP Conf. Ser.: Earth Environ. Sci., 45:1, 012013 (2016) 